DEPÓSITO LEGAL ZU2020000153

Esta publicación científica en formato digital

es continuidad de la revista impresa

ISSN 0041-8811

E-ISSN 2665-0428

Revista

de la

Universidad

del Tunlia

Fundada en 1947

por el Dr. Jesús Emrique Lossada

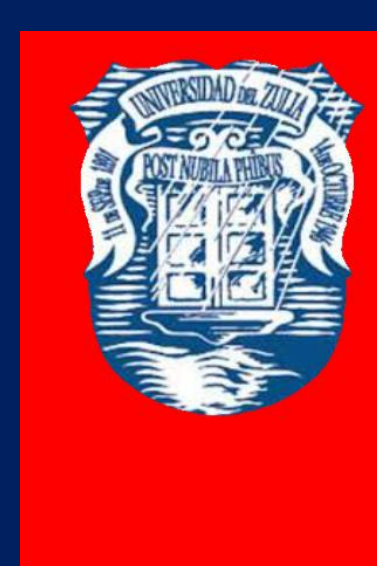

Ciencias

Sociales

y Arte

Aกัต 11 No 31

Septiembre - Diciembre 2021

Tercera ípoca

Maracailbo-Venezuela 


\title{
Video blog as a new channel of socialization of children: the question of the interpretation of the concept
}

Evgenia E. Abrosimova *

\begin{abstract}
The aim of the article is to address the socialization processes of modern children and adolescents, in the context of the characteristics of the information society and the constant presence of the Internet in their lives. A new but emerging phenomenon is emerging, video blogging, which is part of Internet socialization. The main characteristic of this phenomenon is the potential opportunity that children and adolescents have to create an independent video blogging process, which affects the socialization process in general. The empirical data were collected using quantitative and qualitative sociological methods: survey and interview with children. The combination of these methods provides more complete information to understand the problem. The main result of this study is the evidence that around 30\% of children and adolescents are not only viewers of videoblogs, they not only consume the information disseminated by this part of the global network, but also become independent authors of videoblogs. The study results reflect the fact that many children's authors try to imitate their favorite video bloggers. Young Internet users perceive the process of creating a video blog as a certain type of creativity.

KEY WORDS: Internet, socialization, videoblog, children.
\end{abstract}

${ }^{*}$ Candidate of sociological sciences, head of the department of organization of scientific work, VLADIVOSTOK STATE UNIVERSITY OF ECONOMICS AND SERVICE. ORCID: https://orcid.org/0000-0001-8893-4550.E-mail: Ssv@ores.su

Recibido: 09/07/2020

Aceptado: 07/09/2020 
REVISTA DE LA UNIVERSIDAD DEL ZULIA. 3ª época. Año 11 N 31, 2020

Evgenia E. Abrosimova /// Video blog as a new channel of socialization of children... 550-558

DOI: http://dx.doi.org/10.46925//rdluz.31.36

\section{Videoblog como nuevo canal de socialización de los niños: la cuestión de la interpretación del concepto}

RESUMEN

El objetivo del artículo es abordar los procesos de socialización de los niños y adolescentes modernos, en el contexto de las características de la sociedad de la información y la presencia constante de Internet en sus vidas. Está surgiendo un fenómeno nuevo pero emergente, los blogs de video, que es parte de la socialización en Internet. La característica principal de este fenómeno es la oportunidad potencial que tienen los niños y adolescentes de crear un proceso de videoblogueo independiente, lo que afecta el proceso de socialización en general. Los datos empíricos se recopilaron utilizando métodos sociológicos cuantitativos y cualitativos: encuesta y entrevista a niños. La combinación de estos métodos proporciona información más completa para comprender el problema. El principal resultado de este estudio es la evidencia de que alrededor del 30\% de los niños y adolescentes no solo son espectadores de videoblogs, no solo consumen la información difundida por esta parte de la red global, sino que también se convierten en autores independientes de videoblogs. Los resultados del estudio reflejan el hecho de que muchos autores infantiles intentan imitar a sus video bloggers favoritos. Los jóvenes internautas perciben el proceso de creación de un video blog como un cierto tipo de creatividad.

PALABRAS CLAVE: Internet, socialización, videoblog, niños.

\section{Introduction}

Informatization of society has made the Internet space an important part of the everyday life of most modern people. The Internet for a relatively short period of its existence has been involved in all spheres of society - political, economic, and sociocultural. Social processes on-line and off-line are intertwined, mutually flow into each other, often the boundaries between them are blurred. Modern researchers call the new world changeable, fragmented, mosaic, fluid with unstable relations and forms of organization of social life (Asmolov, A. 2008; Parra Contreras, 2020).

The image of modern childhood is also rapidly changing. Representatives of the new generation are formed by the media and advertising, they have a different type of thinking, they are able to access several sources of information at once and are simultaneously in physical and virtual realities. The question of the possible positive and negative consequences of such changes remains open, but it is no exaggeration to say that the 
REVISTA DE LA UNIVERSIDAD DEL ZULIA. 3época. Año 11 N 31, 2020

Evgenia E. Abrosimova /// Video blog as a new channel of socialization of children... 550-558

DOI: http://dx.doi.org/10.46925//rdluz.31.36

Internet and its many services have become as important agents for the socialization of children and adolescents as family and school.

Various Research demonstrate the growing volume of development of the global network and a decrease in the age of entry into the Internet space. New everyday Internet practices are emerging, which should be understood not only interpersonal communication and group communication, but also the purchase of goods, the use of electronic money, watching TV shows and movies, listening to radio stations and music, searching for information, cognitive and game activity, creating groups in social networks and online communities, viewing and creating video blogs. The latter is especially significant because modern children are focused primarily on the consumption of visual information. Most likely, this is the reason for the constantly growing interest of the younger generation in a relatively new phenomenon in the Internet environment - video blogging.

A number of researchers note the fact that the Internet has become a new medium for the socialization of modern children and adolescents.

Some authors have even formulated such terms as "virtual socialization" and "cyber socialization" (Shurbe, V.Z. 2013). This term reflects a new type of socialization, which can both complement the traditional mechanisms of socialization and partially replace them. We can distinguish the following factors of Internet socialization of modern youth: participation in social networks; use of cloud computing resources; Subscribing to online media news the use of leisure services (including computer games); participation in online forums, chats; use of scientific networks; registration and use of electronic libraries; the use of electronic government to solve professional and social problems; application for the transfer of funds online banking (Chistyakov, A.V. 2003; Aniskin et al, 2020).

Video blogging as a factor in immersing children and adolescents in the Internet environment is not mentioned. But if we analyze the basic functions and structure of this phenomenon, then its complexity becomes apparent.

\section{Methodology}

Empirical data were collected using quantitative and qualitative sociological methods. The combination of these methods provides more complete information for 
REVISTA DE LA UNIVERSIDAD DEL ZULIA. 3época. Año 11 N 31, 2020

Evgenia E. Abrosimova /// Video blog as a new channel of socialization of children... 550-558

DOI: http://dx.doi.org/10.46925//rdluz.31.36

understanding the problem. Quantitative methods - questionnaire survey of children; quality methods - interviewing children.

The survey was attended by children and adolescents aged 7-15 years. The choice of age range is due to the fact that modern children enter the Internet quite early, but the conscious choice of content, and sometimes its creation, falls on primary and secondary schools. The survey involved 683 children.

The questionnaire includes 26 questions and is divided into two blocks: the first block of questions aimed at clarifying children's preferences in choosing video blogs, their relationship to video blogging, is addressed to all respondents. The second block was aimed only at those respondents who take an active position in the process of video blogging they conduct their own vlogs. The questions of the second block relate to identifying the features and difficulties of maintaining a video blog, plans for a vlogger child for the further development of video blog. In parallel with the questionnaire, a semi-formalized interview was conducted with children and adolescents.

\section{Results and Discussion}

An open-ended question was integrated into the questionnaire for children and adolescents, allowing respondents to give their own definition of the video blog.

An analysis of the responses of children showed that most often respondents perceived the video blog as "a video in which people talk about their lives." This echoes the traditional definition of a blog, which characterizes it as a "personal diary." Children associate the video blog with the personality of the author, focusing on the fact that the video should contain a personal component, a story about the life of the video blogger.

Another part of the respondents misses the personal component of video content and answers that the video blog is "video on a specific topic". This is consistent with the realities of the modern video blogosphere, which performs various functions, so the content of the video content may not be tied to the identity of the vloger. In a similar context, the video blog is perceived by the part of the respondents who formulated their answer as follows: "information transmitted through the video." The preference for visual information over all other types is one of the reasons for the widespread use of video blogging. 
REVISTA DE LA UNIVERSIDAD DEL ZULIA. $3^{a}$ época. Año 11 N 31, 2020

Evgenia E. Abrosimova /// Video blog as a new channel of socialization of children... 550-558

DOI: http://dx.doi.org/10.46925//rdluz.31.36

Thus, the responses of the child respondents were classified according to two main parameters: 1) the perception of video blogs as the author's personal diary, i.e. video content should contain information about the life of the vlogger; 2) the perception of video blog as a source of some information.

In the course of analyzing the responses of the children participating in the study, the following statements fell into the group perceiving video blogs as the author's personal diary: "A video blog is when you shoot a video about how you spend your day; ... when a blogger walks, taking pictures of himself and performing actions; .... video materials in which you can share your skills and experience, this is your creativity; ... the expression of their thoughts, feelings, emotions; when people show their talents, interests to viewers who like them; ... when a person takes pictures of himself; ... a personal diary in video format; ... a video where the author describes his life in a day or a week; ... a video about events in your life, stories and interesting stories, filmed on video and uploaded to the network in order to share bright events with other people."

The second group of combined answers of respondents contains fewer statements than the previous one. This indicates that most representatives of the children's audience consider video blog an analogue of a personal diary. Representatives of this group formulated their answers as follows: "A video blog is the information that you want to convey through video; ... when a person shoots a video and uploads it to YouTube; ... review in a video on YouTube; ... something is being told"; "A video blog channel containing informative videos about the lifestyle of a blogger"; "A channel containing cognitive content about the world."

It is worth noting that out of the entire sample of survey participants, only two respondents accompanied the definition of video blog with a negative assessment: "A senseless waste of time"; "Meaningless stupid entertainment for mass consumers." However, these statements do not mean at all that these respondents are not involved in the video blogging process.

In a number of children's definitions of video blogging, their specific functions are traced - professional, self-presenting, communicative-entertaining: "A person who makes videos and makes money on it"; "When you shoot on YouTube and you become famous", "the person who makes the 
REVISTA DE LA UNIVERSIDAD DEL ZULIA. 3é época. Año $11 \mathrm{~N}^{\circ}$ 31, 2020

Evgenia E. Abrosimova /// Video blog as a new channel of socialization of children... 550-558

DOI: http://dx.doi.org/10.46925//rdluz.31.36

video and makes money on it", "this is the place where video bloggers exist. They shoot videos, delight children, and thereby earn their living."

It can be seen from the above definitions that children mix the concepts of video blog and video blogger, which is understandable, since vlogs also become active units of social relations.

An analysis of the definitions of video blogs and the children's video blogosphere segment allows us to identify three structural elements of the video blogosphere that are important for discussing its resources and risks - this is children's content created by adults; child-generated content for children and adult content. The last element just causes the most discussion.

The study of children's ideas about video blogs was continued in line with the analysis of the content of the video blogosphere. Respondent children were offered 10 vlog allegations with which they could agree or disagree.

Distribution of answers of respondent's children and adolescents about the content of a good video blog

\begin{tabular}{|c|c|c|}
\hline $\begin{array}{l}\text { № } \\
\Pi / \Pi\end{array}$ & Possible answer & $\%$ \\
\hline & A good vlog should be popular & 50,0 \\
\hline 2 & A good video blog should have a lot of jokes and funny moments & 49,4 \\
\hline 3 & A good vlog should be informative & 44,8 \\
\hline & A good video blog contains no ads & 43,7 \\
\hline 5 & A good video blog should have a lot of effects (music and animation) & 32,9 \\
\hline 6 & A good video blog is any video of my favorite blogger. & 31,8 \\
\hline 7 & In a good video blog always only reliable information & 31,8 \\
\hline 8 & A good video blog is always a lot to discuss & 29,2 \\
\hline & There are very few good videos & 22,2 \\
\hline & A good video blog should be short and clear. & 18,3 \\
\hline
\end{tabular}

According to young users, a good video blog should be, first of all, popular among viewers. For children, ratings are important - they watch those who are popular to be in the 
REVISTA DE LA UNIVERSIDAD DEL ZULIA. 3época. Año 11 N 31, 2020

Evgenia E. Abrosimova /// Video blog as a new channel of socialization of children... 550-558

DOI: http://dx.doi.org/10.46925//rdluz.31.36

know, becoming a victim of the infection effect. Approximately equally vlogs perform entertaining and cognitive functions.

Only $31.8 \%$ of respondents rate all the videos of their favorite vlogger as "good video content", while others approach the assessment more critically, paying attention to related details - the accuracy of the information, the lack of advertising, the use of visual effects, etc.

In the analysis of video content, popular among children and teenagers, it can be concluded that children and adolescents prefer to watch video blogs with fun and easy, not annoying content. Adult vlogers enhance the humorous component, resorting to various animated effects, adding a video of brightness and originality. All rating video bloggers use such techniques as text in a frame, a musical background, a frame-in-frame effect, an insert of cartoon characters, etc. Popular video bloggers are moving away from the amateur video format (video shooting on a mobile phone) using professional equipment, resorting to the help of third parties (videographer), etc.

The main result of this study is the evidence that about 30\% of children and adolescents not only are viewers of video blogs, not only consume the information broadcast by this part of the global network, but also become independent authors of video blogs. The results of the study reflect the fact that many child authors try to imitate their favorite video bloggers. Young Internet users perceive the process of creating a video blog as a certain type of creativity.

For children, the authors important is the creative process of video content. This is evidenced by a high percentage $(91.8 \%$ ) who chose the video creation process as an important and very important goal of creating a video blog. An active position in the process of video blogging allows the child to get the experience that is not available to the child, who is only a spectator. Video blogging contributes to the development of reflection due to the possibility of planning the plot and script, thinking through the text and style of behavior in the frame.

More than half of the active vlogers participating in our study $(55.1 \%)$ noted that other people use the help of video blogging. Most respondents resort to the help of parents (34\%) and friends (27.7\%). 14.3\% of respondents resort to help from brothers and sisters, and only $6 \%$ turn to teachers for help. 
REVISTA DE LA UNIVERSIDAD DEL ZULIA. 3época. Año 11 N 31, 2020

Evgenia E. Abrosimova /// Video blog as a new channel of socialization of children... 550-558

DOI: http://dx.doi.org/10.46925//rdluz.31.36

It should be noted that school teachers, even computer science and social science teachers, are not included as facilitator consultants. However, they remain an important agent of socialization, including through media education of children, therefore, the discovered fact needs additional study

The children's segment of video blogging, namely the activities of child authors, is not always professional in nature. Rather, this type of activity can be described as a new kind of creativity, a new format for the realization of ideas and the potential of childhood. This is a kind of children's hobby, which acts as a "source of socio-cultural activity of the individual and determines the dynamics of the transition from initiative to active sociocultural creativity, leading to the processes of socialization and inculturation of the individual." And in the future - can go to a professional level.

\section{Conclusions}

We can conclude that the modern Internet space has already become an integral environment for the development of the child as a person, i.e. environment of his socialization. The new realities of the information society dictate to him new rules of behavior and new rules of adaptation in a changing world. The video blogosphere, as an integral part of the global network, is a fairly new, but nonetheless very popular pastime for modern children and adolescents. Like all Internet space, the video blogosphere contains certain risks and resources for the potential development of young Internet users. This requires further study. However, already at the present stage, it becomes obvious that video blogging as a process is an incentive for the development of certain personal qualities in children, which cannot but affect the process of socialization as a whole.

A number of researchers note the fact that the Internet has become a new medium for the socialization of modern children and adolescents. The video blog in the representations of children is an important component of their daily lives, creating conditions for creativity and self-realization, communication and development, as well as recreation and entertainment. Its popularity is due to the technical availability of the resource, emotional attractiveness, and various possibilities of satisfying the needs for cognition, communication, and leisure. The video blogosphere as part of the Internet space gives the child the opportunity to feel like an adult, independent and responsible. Thus, 
REVISTA DE LA UNIVERSIDAD DEL ZULIA. 3época. Año 11 N 31, 2020 Evgenia E. Abrosimova /// Video blog as a new channel of socialization of children... 550-558

DOI: http://dx.doi.org/10.46925//rdluz.31.36

video blogging is becoming an important factor in the socialization of children and adolescents in the modern world.

Video blogging includes the characteristics of most media services popular among modern children and young people. Its popularity among the many Internet resources and means of Internet communication is due to the content of the visual component. Most likely, this is the reason for the constantly growing interest of the younger generation in a relatively new phenomenon in the Internet environment - video blogging.

The video blogosphere is that part of the virtual space in which the idols of modern childhood are most concentrated. At the same time, the video blogosphere is not only a translator of information about idols, about their life and work, it is directly a platform for their creation. This makes the video blogosphere as attractive as possible for the younger generation. It is in this environment that a child or teenager gets the opportunity to implement such a psychological mechanism as imitation or copying of examples and patterns of behavior of people around. The child begins to identify with other people. These psychological mechanisms (imitation and identification) are inherent in the real life of the child. In the information society, young users are increasingly finding role models and identifications in the virtual environment.

\section{References}

Aniskin, V.N.; $\quad$ Korostelev, A.A.; $\quad$ Lvovna, B.A.; Kurochkin, A.V.; Sobakina, T.G. (2020). Teaching potential of integrated learning technologies Smart, Stem and Steam, Revista de la Universidad del Zulia, 11 (29), 328-336. DOI: http://dx.doi.org/10.46925//rdluz.29.21

Asmolov, A. (2008) Veld's Syndrome, or a Generation that has gone into the virtual world. https://www.psyh.ru/sindrom-velda-ili-pokolenie-ushedshee-v-virtualnyj-mir/

Chistyakov, A.V. (2003) Socialization of an individual in an online communications society: sociocultural analysis URL: https://search.rsl.ru/ru/record/01003292048

Parra Contreras, R. (2020). Breve reflexión sobre el porvenir de la humanidad, Revista Latinoamericana de Difusión Científica, 2 (2), 4-5. DOI: https://doi.org/10.38186/difcie.22.02

Shurbe, V.Z. (2013) High-tech generation and "new conflict" of generations? URL:https://www.isras.ru/files/File/Socis/2013 4/Shurbe.pdf 